Article

\title{
Gasification of Biochar from Empty Fruit Bunch in a Fluidized Bed Reactor
}

\author{
M. A. Mohd Salleh *, Nsamba Hussein Kisiki, H. M. Yusuf and W. A. Wan Ab Karim Ghani \\ Department of Chemical and Enviromental Engineering Universiti Putra Malaysia, 43400, Serdang, \\ Malaysia; E-Mails: nsambahussein2000@yahoo.com (N.H.K.); hamdan@eng.upm.edu.my (H.M.Y.); \\ wanaz@eng.upm.edu.my (W.A.W.A.K.G.)
}

* Author to whom correspondence should be addressed; E-Mail: asalleh@eng.upm.edu.my; Tel.: +603-89466286; Fax: +603-86567120.

Received: 6 May 2010 / Accepted: 31 May 2010 / Published: 2 July 2010

\begin{abstract}
A biochar produced from empty fruit bunches (EFB) was gasified in a fluidized bed using air to determine gas yield, overall carbon conversion, gas quality, and composition as a function of temperature. The experiment was conducted in the temperature range of $500-850{ }^{\circ} \mathrm{C}$. It was observed that biochar has the potential to replace coal as a gasification agent in power plants. Hydrogen gas from biochar was also optimized during the experiment. High temperatures favor $\mathrm{H}_{2}$ and $\mathrm{CO}$ formation. There was an increase of $\mathrm{H}_{2}$ over the temperature range from $500-850{ }^{\circ} \mathrm{C}$ from $5.53 \%$ to $27.97 \%(\mathrm{v} / \mathrm{v})$, with a heating value of $30 \mathrm{~kJ} / \mathrm{g}$. The $\mathrm{C}$ conversion in the same temperature range increased from $76 \%$ to $84 \%$. Therefore, there are great prospects for the use of biochar from EFB as an alternative fuel in power plants, as a renewable energy providing an alternative path to biofuels. Results from this work enable us to better understand syn gas production under high treatment temperatures.
\end{abstract}

Keywords: biochar; fluidized bed; empty fruit bunch; gasification; hydrogen gas

\section{Introduction}

Increase in green house gases due to biomass decomposition poses great threats with options for going green. The combustion and gasification of coal, a non renewable fuel, results into increased carbon dioxide emissions and over ash accumulation. 
The Malaysian government has put renewable Energy on the forefront in its bid under the Malaysian Plan and the Third Outline Perspective Plan for 2001-2010 (OPP3) [1] in support of the World's efforts to overcome energy threats and fight climate change. Choo et al., 2005 [2] reported that the current oil and gas reserves for Malaysia equal 16 and 32 years, respectively, of service life. Malaysia will be in a total energy scarcity by 2100 if no alternative sources for energy are adopted. The move for the Malaysian government to support renewable energy, especially from biomass, is seen as a clean and environmentally friendly, since the International Energy Agency 2002 reported that most of the emissions come from energy (80\%) and agriculture 20\% [3].The palm oil industry has a role to play in overcoming these global challenges. Gasification of palm waste is seen to offset green house emissions and to reduce the large volumes of ash in coal plants generated, which can power combustion, pyrolysis and gasification plants. This can only be achieved through environmentally and an economically feasible technology.

Gasification is the thermal conversion of solid material into a gaseous product in a limited air supply at higher temperatures. Malaysia is one of the largest producers of palm oil in the World today, with a variety of empty fruit bunches as waste from the palm oil industry. Reports from the Malaysian Palm Oil Industry Performance, 2009 [1] report that in the year 2008, Malaysia produced 17.7 million tonnes of palm oil on 4.5 million hectares of land. Furthermore, Malaysia ranked as the second largest producer of Palm oil in the World Growth Oil Green Development campaign, 2009 [4]. This portrays its potential for sustainable wastes from palm oil residues. A report from the United Nations Framework Convention on Climate change, UNFCCC, 2006 [5] on clean Development Mechanism revealed that making use of the waste from palm oil empty fruit bunch EFB waste would reduce $\mathrm{CO}_{2}$ reductions by 25,139 tonnes per year. Since the year 2000, the production of EFB is over 16 million tonnes every year, which is discarded as waste .This waste has been pyrolyzed for primary products like oil and generating 2030\% EFB char. The char generated is mostly useful for further application because it is a very reactive material. Gasification of this char is one of the most promising routes.

Rao et al., 2001 [6] investigated the kinetic parameters of char gasification under treatment temperatures of $750-900{ }^{\circ} \mathrm{C}$ under $\mathrm{CO}_{2}$ treatment: his results were in agreement with other values on char gasification in literature. Fluidized beds are a choice of practical application for this purpose due to the high heat and mass transfer rates and the even temperature distribution compared to all other reactors, with attention from many researchers. Ocampo et al. [7] performed a study on coal char gasification characteristics at different steam/coal and air/coal ratios and temperatures of gasifying agent in a fluidized bed. Bayarsaikhan et al. 2006 [8] studied steam gasification of a Victorian brown coal in an atmospheric bubbling fluidized bed reactor with continuous feeding of the coal. From Chatterjee, 1995 [9], gasification of a high-ash India coal in a laboratory-scale, atmospheric fluidized bed gasifier using steam and air as fluidizing media was studied. The variation of product gas composition, calorific value, bed temperature and carbon conversion with oxygen and steam feed was discussed, and the experimental data were compared with the predicted.

The gasification characteristics for a sub-bituminous coal with an air-steam mixture in a pressurized fluidized bed gasifier were studied by Huang et al., 2003 [10]. Kim et al., 1996 [11] investigated the gasification of Australian coal in an internally circulating fluidized bed with a draft tube. His emphasis was on the effects of temperature, coal feed rate and steam to coal mass ratio, oxygen to coal biomass ratio on product gas composition, cold gas efficiency, carbon conversion, calorific value and gas yield. 
Kikuchi et al., 1985 [12], Gutierrez and Watkinson, 1982 [13] and Crnomarkovic et al. 2007 [14] did similar work aimed at the same study. Cousins et al., 2006 [15], investigated the reactivity of chars formed in fluidized bed gasifiers discovered a rapid decrease in char reactivity during its formation as part of the pyrolysis of the coal. Liu et al., 2004 [16], investigated the effects of pyrolysis time and found that a longer pyrolysis time led to lower reactivity of a char, while this effect leveled off as pyrolysis time increased. Guo et al., 2008 [17], studied the changes in char structure during the gasification of brown coal in a fluidized bed/fixed bed reactor. In 2004, Li et al. [18] performed biomass gasification tests in a pilot-scale air-blown circulating fluidized bed gasifier. When air is used as the gasifying agent, the main products include $\mathrm{C}_{2} \mathrm{H}_{4}, \mathrm{C}_{2} \mathrm{H}_{2}, \mathrm{H}_{2}, \mathrm{CO}, \mathrm{CO}_{2}, \mathrm{CH}_{4}, \mathrm{C}_{2} \mathrm{H}_{6}$ and $\mathrm{N}_{2}$, with a solid phase consisting of char, inorganic ash and condensable aromatic hydrocarbons called tars. Encinar and co-workers, 2002 [19,20], carried out isothermal experiments on steam gasification of Cynara cardunculus between 300 and $800{ }^{\circ} \mathrm{C}$ in a fixed bed, and found that particle size, nitrogen flow rate, and initial sample weight generally did not exert any influence, whereas temperature was very significant. Dyk et al., 2006 [21], studied the effect of temperature and gasification medium with the aim of optimizing co-gasification of coal and wastes for Sasol-Lurgi gasifiers. Boon and co-workers, 1994 [22], identified three distinct stages in the formation of char from microcrystalline cellulose at low temperatures. Below $250{ }^{\circ} \mathrm{C}$, the oligosaccharides were preserved, but the color of the char and its FTIR spectra indicated the formation of unsaturated C-C bonds and carbonyl groups, probably due to water loss. Despite their efforts, there is need for a clear understanding of the temperature effects on the EFB char. The aim of this research is to optimize the production of hydrogen from EFB char under high treatment temperatures. Chars derived from biomass are gasified because they are a promising feedstock for hydrogen production and gas synthesis (H2 + CO). Through Fischer-Tropsch technology, the synthesized gas can be converted to liquid fuels.

\section{Methodology}

\subsection{Material and Methods}

EFB char samples were from Nasmech Technologies Sdn Bhd. The process of their manufacture involves pyrolysis of the EFB wastes under a size range of 400-500 mm operated under a rotary drum at temperatures in the range of $300{ }^{\circ} \mathrm{C}-350{ }^{\circ} \mathrm{C}$ via slow pyrolysis in a batch process at atmospheric pressure. Slow pyrolysis is the controlled thermal conversion of EFB in the absence of oxygen at temperatures of $300{ }^{\circ} \mathrm{C}-350{ }^{\circ} \mathrm{C}$ under a longer residence time. This process evolves tars, volatiles and chars. The char as received has a moisture content $5.4 \%$, the size of the chars is in the ranges of $2-5 \mathrm{~mm}$. The char was further ground to a mean size diameter of $500 \mu \mathrm{m}$. The char was oven dried at $105{ }^{\circ} \mathrm{C}$ to dry-off any remaining water. The proximate and ultimate analyses were performed using ASTM methods [23].

\subsection{Gasification}

The process of gasification was performed on a laboratory scale at atmospheric pressure in a fluidized bed gasification system (Figure 1). A known EFB char mass sample was put in the reactor on a batch system under the air flow rate of 5 liters/minute through manual loading. After reaching the desired temperature, compressed air was supplied for gasification and fluidization through the bottom 
of the gasifier at a constant flow rate. The air supply to the gasifier bed and feeder were controlled and monitored using two flow meters and two valves separately. The gasifier was heated by a tube furnace from $500{ }^{\circ} \mathrm{C}-850{ }^{\circ} \mathrm{C}$ at an increment of $100{ }^{\circ} \mathrm{C}$ per new run. The gasifier had an inside diameter of $4 \mathrm{~cm}$ and a length of $40 \mathrm{~cm}$. The thermocouples collected temperatures of at three different locations of the gasifier: measuring the bottom temperature, the temperature in the middle of the gasifier and the temperature at the top. The hot gas was cooled to about $20^{\circ} \mathrm{C}$ by a water-cooled condenser. The condensed gas collected in the flask and the particulates then filtered. The gas passed through a dessiccator column to remove the moisture in the gas before collecting gas samples in the gas bags. The gas was collected in an air tight gas bag whose maximum capacity was 12 liters and would fill up every 2 minutes, after which it was replaced with another empty gas bag until the end of the experiment. A total of 6 gas bags per run was collected and analyzed offline. Each experiment was done in duplicate and results were in good consistency.

Figure 1. The experimental setup: schematic (left panel) and image (right panel).
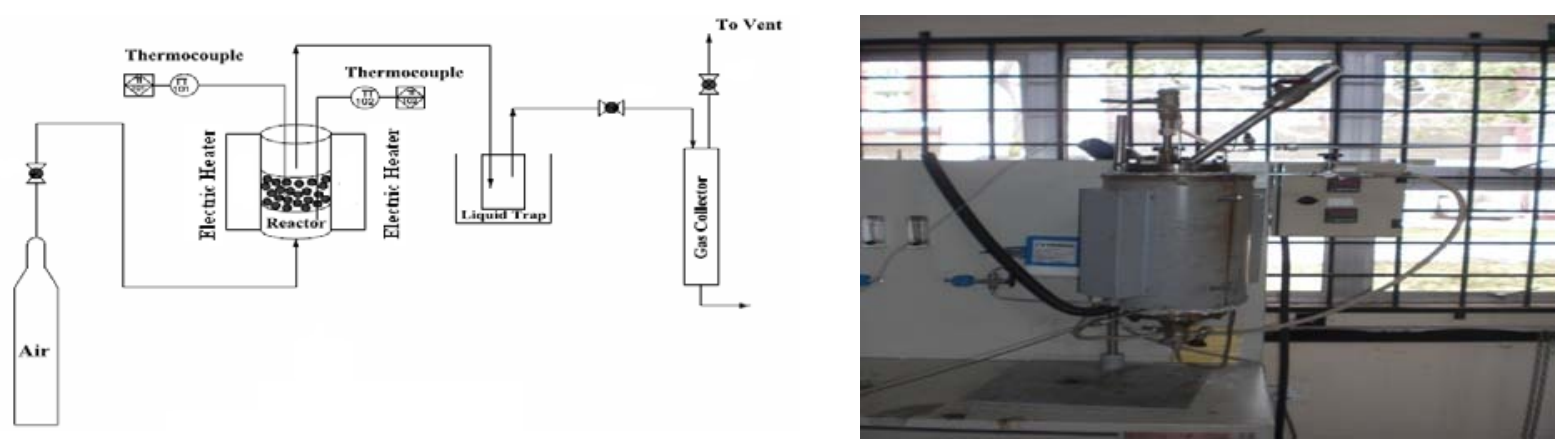

Gas samples were collected in gas bags and taken for analysis per 2 minute collection interval using an off-line GC gas analysis system (GC) (Model: Agilent G1530N, Germany, Agilent Technologies, Inc. Serial number CN10710068) equipped with a thermal conductivity detector (TCD). A GC calibration was performed using a certified standard gas prior to each test. High-purity Argon was used as the carrier gas. The off-line GC analysis system could detect $\mathrm{H}_{2}, \mathrm{CO}, \mathrm{CO}_{2}, \mathrm{O}_{2}, \mathrm{CH}_{4}$ and $\mathrm{N}_{2}$. Calculation of the high heating value follows (where $\mathrm{C}$ is the weight fraction of carbon; $\mathrm{H}$ of hydrogen; $\mathrm{O}$ of oxygen; $\mathrm{A}$ of ash; $\mathrm{S}$ of sulfur and $\mathrm{N}$ of nitrogen appearing in the Ultimate analysis).

$$
\mathrm{HHV}(\text { in } \mathrm{kJ} / \mathrm{g})=0.3491 \mathrm{C}+1.1783 \mathrm{H}-0.1034 \mathrm{O}-0.0211 \mathrm{~A}+0.1005 \mathrm{~S}-0.0151 \mathrm{~N}
$$

Table 1. Volume of Product gas composition as quantified from GC Analysis.

\begin{tabular}{ccccccc}
\hline $\begin{array}{c}\text { Size }=\mathbf{5 0 0} \boldsymbol{\mu m} \\
\text { Original mass } \\
\text { (grams) }\end{array}$ & $\begin{array}{c}\text { Temp } \\
\left({ }^{\circ} \mathbf{C}\right)\end{array}$ & $\mathbf{H 2}$ & $\mathbf{C 0}$ & $\mathbf{C 0 2}$ & $\mathbf{C H 4}$ & Ash (grams) \\
\hline 50.00 & 500 & 1.992 & 0.620 & 0.997 & 0.144 & 12.00 \\
58.00 & 600 & 4.272 & 0.650 & 0.914 & 0.603 & 11.77 \\
50.00 & 700 & 5.40 & 0.615 & 0.873 & 0.900 & 9.55 \\
50.00 & 750 & 6.14 & 0.564 & 0.830 & 1.604 & 8.45 \\
51.11 & 800 & 9.52 & 0.984 & 0.711 & 1.794 & 8.45 \\
50.00 & 850 & 10.07 & 1.000 & 0.698 & 1.680 & 7.95 \\
\hline
\end{tabular}




\section{Results and Discussion}

Fuel properties indicate an ultimate analysis of: $61.51 \%$ carbon, $10.51 \%$ hydrogen, $26 \%$ oxygen and $1.98 \%$ nitrogen, while for proximate analysis: volatile matter $25.38 \%$, fixed carbon, $54.05 \%$, moisture content $5.4 \%$ and $\mathrm{HHV}$ of $30.818 \mathrm{~kJ} / \mathrm{g}$. Results below show the single char particle structure.

Figure 2. Diameter of single char.

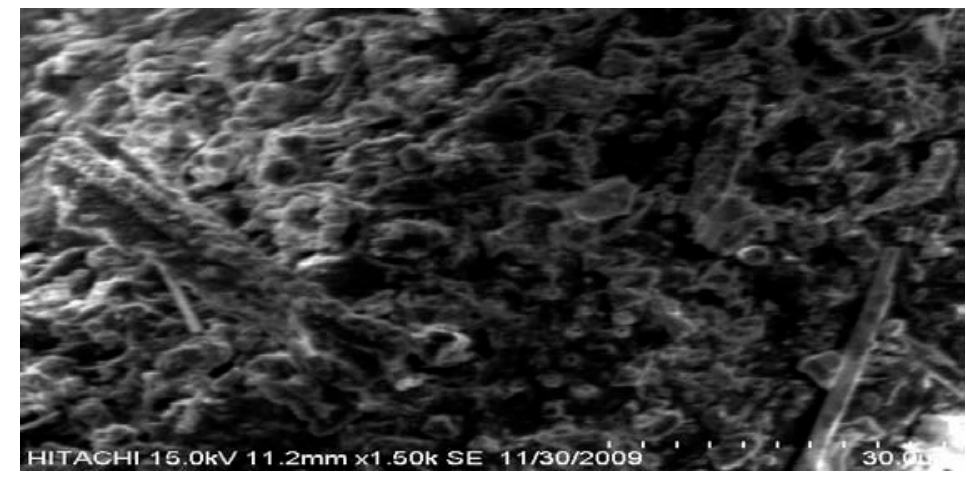

Figure 3. The pore distribution.

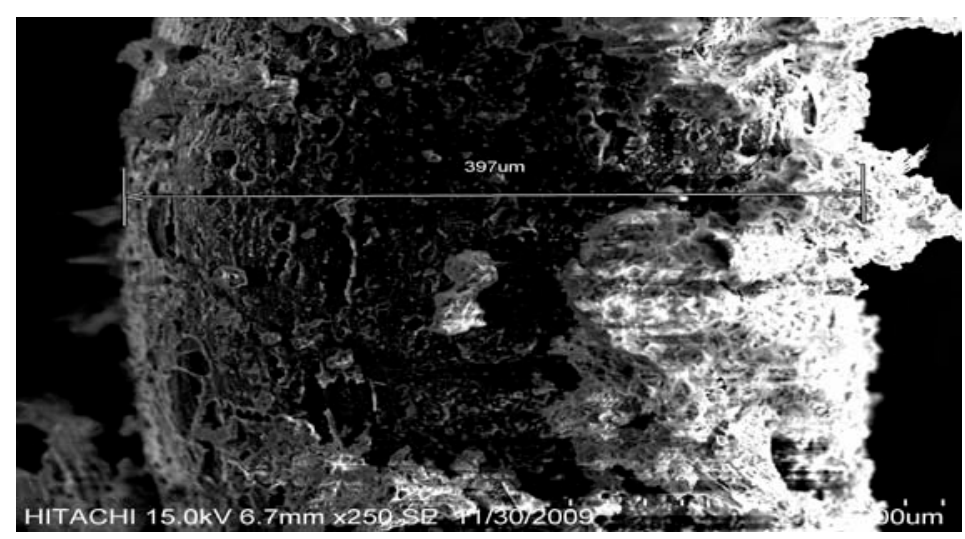

From the analysis of the metal components by Scanning Electron Microscopy (SEM), we identify metallic elements such as magnesium $(\mathrm{Mg})$, silicon $(\mathrm{Si})$, phosphorus $(\mathrm{P})$, zinc $(\mathrm{Zn})$, copper $(\mathrm{Cu})$, manganese (Mn), titanium (Ti) and yttrium (Y), as can be seen in Figure 4. The presence of these metallic elements plays an important role during the gasification process at higher temperatures. At higher temperatures, these metallic elements decompose and act as catalysts in the chemical reactions that take place during the evolution of the product gases. Ganga et al., 2000 [24] reported that the gasification reactivity of a char depends on the nature and quantity of the metals (indigenous or added) present in the char, the heat treatment temperature (HTT), the heat treatment time or residence time (Rt) and the nature of the reactant gas. Table 2 shows the metals present in char. 
Figure 4. SEM peaks for elemental identification.

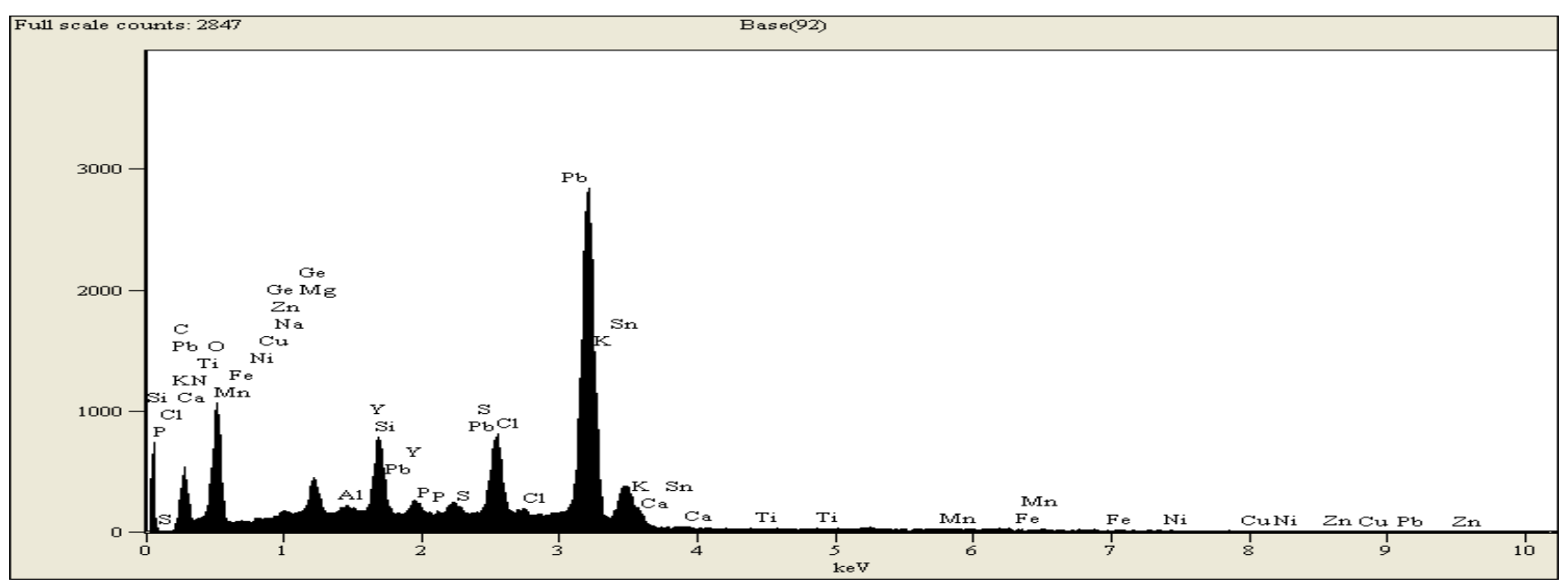

Table 2. Volume of the product gas per gram of biochar.

\begin{tabular}{|c|c|c|c|c|c|c|}
\hline \multirow{2}{*}{$\begin{array}{c}\text { Size }=500 \mu \mathrm{m}, \\
\text { flowrate }=5 \mathrm{~L} / \mathrm{min} \\
\text { Original mass (grams) }\end{array}$} & \multirow{2}{*}{$\begin{array}{c}\text { Temp } \\
\left({ }^{\circ} \mathrm{C}\right)\end{array}$} & \multicolumn{4}{|c|}{ Volume in $\mathrm{ml} /$ gram } & \multirow{2}{*}{ Conversion \% } \\
\hline & & $\mathbf{H}_{2} / \mathbf{g}$ & $\mathrm{CO} / \mathrm{g}$ & $\mathrm{CO}_{2} / \mathrm{g}$ & $\mathrm{CH}_{4} / \mathrm{g}$ & \\
\hline 50.00 & 500 & 39.84 & 12.4 & 19.94 & 2.88 & 76.00 \\
\hline 58.00 & 600 & 73.65 & 11.18 & 15.75 & 10.38 & 79.77 \\
\hline 50.00 & 700 & 108 & 12.3 & 17.45 & 18 & 80.90 \\
\hline 50.00 & 750 & 111.63 & 10.25 & 15.09 & 29.17 & 82.00 \\
\hline 51.11 & 800 & 173.1 & 17.89 & 12.93 & 32.6 & 83.00 \\
\hline 50.00 & 850 & 201.4 & 20 & 13.95 & 33.6 & 84.00 \\
\hline
\end{tabular}

\section{Effect of Temperature}

Temperature not only affects the product gas yield but also controls the process energy input. The gas yields of $\mathrm{H}_{2}$ and $\mathrm{CO}$ increased as the temperatures increased, while $\mathrm{CO}_{2}$ and $\mathrm{CH}_{4}$ decreased. It was observed that the total gas yield increased monotonically with temperature. According to Le Chatelier's principle, higher temperatures favor the reactants in the exothermic reactions and the products in the endothermic reactions. It is evident to have increasing $\mathrm{H}_{2}$ and $\mathrm{CO}$, which are the most important gases in syn gas production because the reactions are favored towards the reactant side at high temperatures. Increasing temperature in the regions of $500{ }^{\circ} \mathrm{C}-850{ }^{\circ} \mathrm{C}$ increase the production of $\mathrm{H}_{2}$ gas and $\mathrm{CO}$, with a decrease in $\mathrm{CO}_{2}$ and $\mathrm{CH}_{4}$. As the temperature increases, both carbon and methane are reformed to form $\mathrm{H}_{2}$ and $\mathrm{CO}$. This accounts for the increased concentration of $\mathrm{H}_{2}$ and CO. Increasing the temperature up to a maximum threshold leads to a maximum yield of $\mathrm{H}_{2}$, beyond which it cannot increase any more, but decreases. This is due to the Water gas shift (WGS) reaction, which is sensitive to temperature increase with tendency to shift the reaction towards the reactants according to Le-Chatelier's principle. Mansary et al. 1999 [25] made the same observations when he studied the air gasification of rice in a fluidized bed. Use of biomass to bio oil has taken on a commercial movement. For example, Dalai in 2003 [26] reported that two commercial plants. Ensyn Technologies Inc. in Ottawa, Canada is being operated by Red Arrow Products Co. WI (50 tonnes/day). Also, a pilot 
demonstration unit (three tonnes/day) is being operated in Galcia, Spain, using a bubbling fluidized bed using fast pyrolysis and generating 15\% bio char, 15\% gas and $70 \%$ liquid.

\section{Carbon Conversion Efficiency and HHV}

Higher temperature increases the process of gasification and increases the process of carbon conversion. At higher temperatures, there is higher heat transfer within the char and more of it is gasified. The presence of high syngas content at higher temperature contributes to the production of a high heating value gas suitable for exploitation in internal combustion engine and turbines for power production.

Figure 5. volume of $\mathrm{H}_{2}$ and $\mathrm{CO}(\%)$.

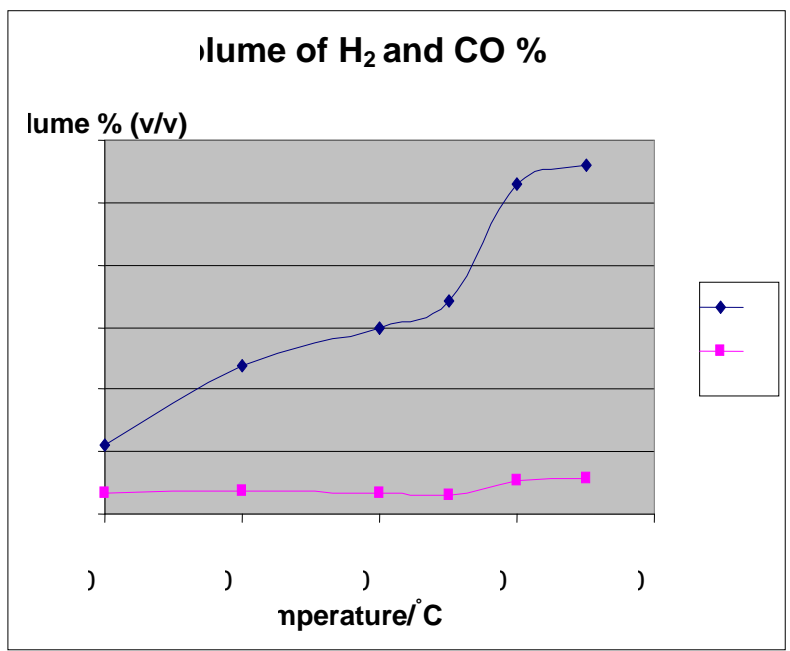

Figure 6. volume of $\mathrm{CH}_{4}$ and $\mathrm{CO}_{2}(\%)$.

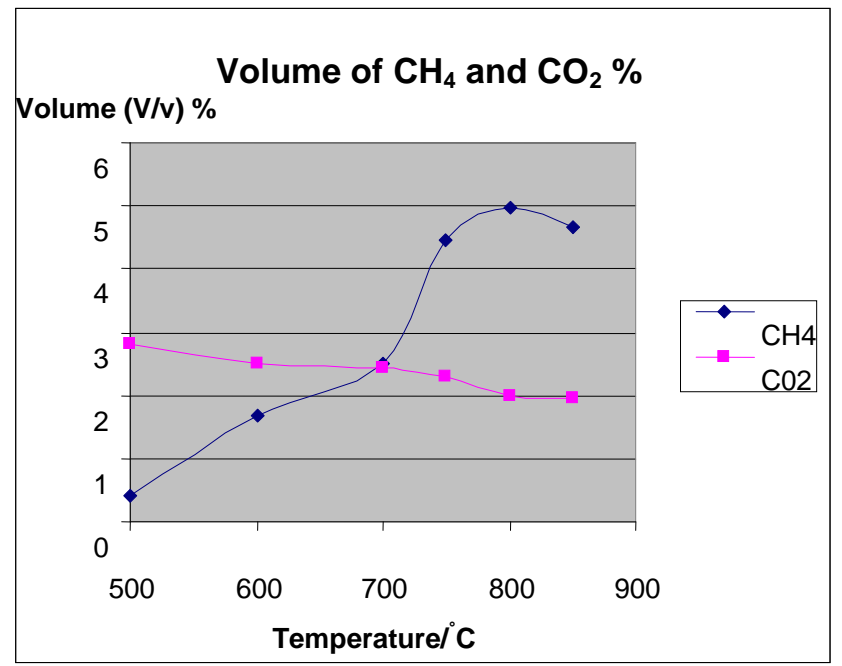




\section{Conclusions}

Experiments were conducted to investigate the effect of temperature on the product gas composition, gas quality, heating value and char composition. Results reveal that temperature is a very significant factor in the production of a $\mathrm{H}_{2}$ rich gas. Total syn gas yield increased from $6.1 \%$ to $42.4 \%$ with an optimum value of $27.97 \%(\mathrm{v} / \mathrm{v}) \mathrm{H}_{2}$ with the increase of gasification temperature from $500{ }^{\circ} \mathrm{C}-850^{\circ} \mathrm{C}$. The results indicate a very promising possibility of producing hydrogen and syn gas from chars derived from empty fruit bunch through cheap air gasification.

\section{Acknowledgments}

Special thanks to the Ministry of Science, Technology and Innovation Malaysia (MOSTI) for sponsoring the work under grant TF 0308D038.

\section{References}

1. Malaysian Palm Oil Industry Performance 2008. In Global Oils \& Fats Business Magazine; 2009; Volume 6, Issue 1. Available online: http://www.mpoc.org.my/gofbm_download.aspx?id= ff6cb4c8-9863-49b2-ae12-ee5e2d5d1f0a (accessed on 30 May 2010).

2. Choo, Y.M.; Ngan, M.; Chan, K.W.; Basiron, Y. An option for greenhouse gas mitigation in the energy sector. J. Oil Palm Res. 2005, 17, 47-52.

3. CO2 Emissions from Fuel Combustion 1971-2000, 6th ed.; International Energy Agency, OECD: Paris, France, 2002; p. 105.

4. World Growth Palm Oil Green Development Campaign. Palm Oil—The Sustainable Oil A Report by World Growth. Available online: http://www.worldgrowth.org/assets/files/Palm_Oil.pdf (accessed on 30 May 2010).

5. Sahabat Empty Fruit Bunch Biomass Project. Available online: http:/cdm.unfccc.int/ UserManagement/FileStorage (accessed on 30 May 2010).

6. Rao, T.R.; Ashish, B.; Bheemarasetti, J.V.R. Kinetics of rice husk char gasification. Energy Convers. Manag. 2001, 42, 2061-2069.

7. Ocampo, A.; Arenas, E.; Chejne, F.; Espinela, J.; London^o, C.; Aguirrea, J.; Perez, J.D. An experimental study on gasification of Colombian coal in fluidized bed. Fuel 2003, 82, 161-164.

8. Bayarsaikhan, B.; Sonoyama, N.; Hosokai, S. Inhibition of steam gasification of char by volatiles in a fluidized bed under continuous feeding of a brown coal. Fuel 2006, 85, 340-349.

9. Chatterjee, P.K.; Datta, A.B.; Kundu, K.M. Fluidized bed gasification of coal. Can. J. Chem. Eng. 1995, 73, 204-210.

10. Huang, J.; Fang, Y.; Chen, H.; Wang, Y. Coal gasification characteristic in a pressurized fluidized bed. Energy Fuels 2003, 17, 1474-1479.

11. Kim, Y.J.; Lee, J.M.; Kim, S.D. Coal gasification characteristics in an internally circulating fluidized bed with draught tube. Fuel 1997, 76, 1067-1073.

12. Kikuchi, K.; Suzuki, A.; Mochizuki, T.; Endo, S.; Imai, E. Ash agglomerating gasification of coal in a spouted bed reactor. Fuel 1985, 64, 368-372. 
13. Gutierrez, L.A.; Watkinson, P.A. Fluidized-bed gasification of some Western Canadian coals. Fuel 1982, 61, 133-138.

14. Crnomarkovic, N.; Repic, B.; Mladenovic, R.; Neskovic, O.; Veljkovic, M. Experimental investigation of role of steam in entrained flow coal gasification. Fuel 2007, 86, 194-202.

15. Cousins, A.; Paterson, N.; Dugwell, D.R.; Kandiyoti, R. An investigation of the reactivity of chars formed in fluidized bed gasifiers: The effect of reactionconditions and particle size on coal char reactivity. Energy Fuels 2006, 20, 2489-2497.

16. Liu, H.; Kaneko, M.; Luo, C.H.; Kato, S.; Kojima, T. Effect of pyrolysis time on the gasification reactivity of char with $\mathrm{CO}_{2}$ at elevated temperatures. Fuel 2004, 83, 1055-1061.

17. Guo, X.; Tay, H.L.; Zhang, S.; Li, C.Z. Changes in char structure during the gasification of a Victorian brown coal in steam and oxygen at $800{ }^{\circ} \mathrm{C}$. Energy Fuels 2008, 22, 4034-4038.

18. Li, X.T.; Grace, J.R.; Lima, C.J. Biomass gasification in a circulating fluidized bed. Biomass Bioenergy 2004, 26, 171-193.

19. Encinar, J.M.; Gonza'lez, J.F.; Gonza'lez, J. Fixed-bed pyrolysis of Cynara cardunculus L. Product yields and compositions. Fuel Process.Technol. 2000, 68, 209-222.

20. Encinar, J.M.; Gonza'lez, J.F.; Gonza'lez, J. Steam gasification of Cynara cardunculus L. Influence of variables. Fuel Process. Technol. 2002, 75, 27-43.

21. Dyk, J.C.; Keyser, M.J.; Coertzen, M. Syngas production from South African coal sources using Sasol-Lurgi gasifiers. Int. J. Coal Geol. 2006, 65, 243-253.

22. Boon, J.J. Cellulose char structure: A combined analytical Py-GC-MS, FTIR, and NMR study. Carbohydr. Res. 1994, 262, 27.

23. Annual Book of ASTM Standards; American Society of Testing Materials: Philadelphia, PA, USA, 1993; Volume 1994, Section 5, pp. D3172-D3189.

24. Devi, T.G.; Kannan, M.P. Gasification of biomass chars in air-Effect of heat treatment temperature. Energy Fuels 2000, 14, 127-130.

25. Mansary, K.G.; Ghaly, A.E.; Al-Taweel, A.M.; hamdullahpur, F.; Ugursal, V.I. Air gasification of rice husk in a dual distributor type fluidized bed gasifier. Biomass Bioenergy 1999, 4, 315-332.

26. Dalai, A.K; Chaudhari, S.T.; Bakhshi, N.N. Production of hydrogen and/or syngas $\left(\mathrm{H}_{2}+\mathrm{CO}\right)$ via steam gasification of biomass-derived chars. Energy Fuels, 2003, 17, 1062-1067.

(C) 2010 by the authors; licensee MDPI, Basel, Switzerland. This article is an Open Access article distributed under the terms and conditions of the Creative Commons Attribution license (http://creativecommons.org/licenses/by/3.0/). 